\title{
Donations to Outgroup Charities, but Not Ingroup Charities, Predict Helping Intentions Toward Street-Beggars in Sweden
}

Arvid Erlandsson, Artur Nilsson, Gustav Tinghög, David Andersson and Daniel Västfjäll

The self-archived postprint version of this journal article is available at Linköping University Institutional Repository (DiVA):

$\underline{\text { http://urn.kb.se/resolve?urn=urn:nbn:se:liu:diva-159125 }}$

N.B.: When citing this work, cite the original publication.

Erlandsson, A., Nilsson, A., Tinghög, G., Andersson, D., Västfjäll, D., (2019), Donations to Outgroup Charities, but Not Ingroup Charities, Predict Helping Intentions Toward Street-Beggars in Sweden, Nonprofit and Voluntary Sector Quarterly, 48(4), 814-838.

https://doi.org/10.1177/0899764018819872

Original publication available at:

https://doi.org/10.1177/0899764018819872

Copyright: SAGE Publications (UK and US)

http://www.uk.sagepub.com/home.nav 
THE RELATION BETWEEN CHARITABLE DONATIONS AND HELPING BEGGARS

NOTE: This is an author copy of the published article, there might be minor differences.

Please cite as: Erlandsson, A., Nilsson, A., Tinghög, G., Andersson, D., \& Västfjäll, D. (2018). Donations to outgroup-charities, but not ingroup-charities, predict helping intentions towards street-beggars in Sweden. Nonprofit and Voluntary Sector Quarterly. doi:10.1177/0899764018819872) 
THE RELATION BETWEEN CHARITABLE DONATIONS AND HELPING BEGGARS

Donations to outgroup-charities, but not ingroup-charities, predict helping intentions towards street-beggars in Sweden

\title{
Arvid Erlandsson
}

\author{
Artur Nilsson
}

Gustav Tinghög

David Andersson

Daniel Västfjäll

AE (corresponding author): Linköping University, Department of Behavioral Sciences and Learning. Phone: +46722000452. E-mail: arvid.erlandsson@liu.se.

AN: Lund University, Department of Psychology. Phone: +46736399011. E-mail: artur.nilsson@psy.lu.se.

GT: Linköping University, Department of Management and Engineering. Phone: +4613282582 . E-mail: gustav.tinghog@liu.se.

DA: Linköping University, Department of Management and Engineering. Phone: +4613282534. E-mail: david.andersson@liu.se.

DV: Linköping University, Department of Behavioral Sciences and Learning \& Decision Research, Eugene, OR. Phone: +4613282059. E-mail: daniel.vastfjall@liu.se.

Keywords: philanthropy in Sweden; helping street beggars; donation behavior; outgroup/ingroup helping, helpful personality; international/domestic charitable giving. 
Donations to outgroup-charities, but not ingroup-charities, predict helping intentions towards street-beggars in Sweden

\begin{abstract}
This paper investigates how donation behavior to charitable organizations and helping intentions towards begging EU-migrants are related. This question was tested by analyzing surveyresponses from 1050 participants sampled from the general Swedish population. Although the overall results suggested that donations to charitable organizations were positively related to helping intentions toward beggars, the results differed substantially as a function of whether the organization was perceived to focus its efforts on outgroup-victims or on ingroup-victims. Specifically, whereas donation behavior toward outgroup-focused organizations clearly predicted more helping intentions toward beggars (also when controlling for demographics, education, income, religiosity and political inclination), donation behavior toward ingroup-focused organizations predicted slightly less helping intentions towards beggars. We conclude that the type of charitable organization a person donates to might tell us more about his or her values and preferences than merely whether or not s/he donates at all.
\end{abstract}

Keywords: philanthropy in Sweden; helping street beggars; donation behavior; outgroup/ingroup helping, helpful personality; international/domestic charitable giving. 
This paper investigates how two different kinds of helping (helping street beggars and donating money to charitable organizations) are related to each other in the extensive welfare state of Sweden. The main research question is whether a Swede who conducts helping of one kind (donating to charitable organizations) is more or less likely to conduct helping of another kind (helping beggars). Sweden is a prime example of the Nordic welfare model, which is traditionally characterized by high standards of living, low social inequality, a generous and universal welfare system, and egalitarian labor markets (Djuve et al., 2015). More recently, the Swedish public policy and media has arguably emphasized globalism, feminism, and anti-racism more than most other countries, and Sweden's immigration policy for refugees has been comparably generous (Dustmann et al., 2016). While some people think that this development is too slow and that more should be done, an increasing number of Swedes are moving in the opposite direction, which makes Sweden more ideologically polarized (Mella, Ahmadi \& Palm, 2013). One example of polarization can be seen in Swedish people's attitudes toward beggars.

\section{Street begging in Sweden.}

In the past, the Swedish welfare state used to rely on a strict regulation of entry and residence on the one hand, and generous tax-financed support to all those legally staying in Sweden on the other (Djuve et al., 2015). Street-begging was therefore uncommon and those who begged were almost exclusively single men with substance addictions (Socialstyrelsen, 2013). However, due to the EU regulations of free mobility accepted in 2004, poor people from other European nations can now (spring 2018) legally stay in Sweden for three months (Socialstyrelsen, 2013; Boeryd, 2014). This has, among other things, resulted in a large increase of EU-migrants mostly from Romania and its neighboring countries coming to Sweden in order to earn money. Although a few of these EU-migrants manage to find a job in Sweden, most of them earn their 
money by street begging. Many, but not all, begging EU-migrants belong to the ethnic group of Roma - one of the most marginalized and discriminated groups in Europe (Djuve et al, 2015; Valfridsson, 2016). Begging can be done in different ways (e.g. selling magazines or playing an instrument) but one of the most common ways of begging in Sweden is to sit outside a grocery store with a mug and request money from the people who pass by. Although most people ignore the beggars, occasionally passers-by do put some coins or bills in the mug or give cans and bottles (which can be recycled for store credit or cash money in Sweden), or even food, clothes, and appliances to the beggars. The average daily income of a begging EU-migrant in Sweden is around 100-200 SEK (\$11-22), which is very low by Swedish standards but much higher than what they can legally earn in their home country (Valfridsson, 2016).

The Swedish welfare system was not prepared for the sudden increase in the number of begging EU-migrants that occurred in 2012 (Valfridsson, 2016). Having beggars visible in public spaces caused unease among the public because of the Swedish welfare tradition that made begging a remainder of a past unjust society, and because it became obviously unclear who had the responsibility to help them. Whereas neighboring countries such as Denmark and Norway opted for policy positions that made it difficult or even illegal for EU-migrants to beg, the Swedish public policy has, as of spring 2018, been more generous (Boeryd, 2014). People are allowed to beg in most public spaces and public funds are given to NGOs who help begging EUmigrants in Sweden. However, the existence of street beggars in Sweden is a controversial and polarizing topic both among politicians and the public, and while some people are openly negative and even hostile toward them, and want to implement strict laws against begging, others are sympathetic toward beggars, perceive their plight primarily as a result of systematic 
THE RELATION BETWEEN CHARITABLE DONATIONS AND HELPING BEGGARS

discrimination and prejudice and spend considerable time and effort to help them (Holmqvist \& Karlsson, 2015; Valfridsson, 2016).

Attitudes and helping intentions toward begging EU-migrants have hardly been systematically researched in Sweden previously and much of the research on begging that had been carried out in other countries is outdated, lacks generalizability, and/or focuses exclusively on beggars from the potential helpers' own country (e.g. Lockard et al., 1976; Goldberg, 1995). In this study, we measured helping intentions toward begging EU-migrants by letting Swedish participants from a roughly nationally representative sample rate the likelihood that they would perform 21 different prosocial acts toward begging EU-migrants anytime during the coming 12 months.

\section{Charitable giving in Sweden}

It has been argued that the Swedish (Nordic) civil society has transformed from "half movement, half government" in the $20^{\text {th }}$ century into "half charity, half business" in the $21^{\text {st }}$ century (Wijkström, 2011). As a result, the Swedish charitable sector has grown rapidly in the past decade (3.76 billion SEK donated in 2007, 8.74 billion in 2017; FRII, 2018) and there are currently over 400 charitable organizations registered at (and monitored by) the Swedish Fundraising Control. In a population study about civic engagement conducted in 2014 , it was found that $80 \%$ of the Swedish respondents claimed to have donated money to a charity organization during the past year, and the mean donation among those donating was 1745 SEK $(\approx \$ 190 ;$ Vamstad, 2015)

Of particular importance for the current study, different charity organizations focus on different causes and try to help different victims (Micklewright \& Schnepf, 2009; Casale \& Baumann, 2013). The question about which charities donors support is under-researched 
compared to questions about whether and how much they give (Neumayr \& Handy, 2017; Breeze, 2013). Charitable organizations can be classified in many ways but the two most common distinctions are between 'people-charities' and 'animal-charities' and between 'international charities' and 'domestic charities' (Breeze, 2013; Rajan, Pink \& Dow, 2009). In our operationalization, charitable organizations with an international outgroup focus (henceforth 'outgroup-organizations') primarily provide help to people in developing countries suffering from poverty-related causes, natural disasters, or war. Organizations with a domestic in-group focus (henceforth 'ingroup-organizations') primarily provide help to people in the same country where they request donations (in this case Swedish people). Many, but not all, ingrouporganizations focus on medical research and awareness-raising about illnesses or disabilities prevalent in the country where the donor lives (e.g. cancer, rheumatism, cardiovascular diseases). Also, some charity organizations focus not on humans but on the environment or on non-human animals (henceforth 'environmental organizations'). In this paper, we classify charitable organizations either as environmental organizations, outgroup-organizations, or ingrouporganizations and the main comparison will be between the two latter categories.

Most research on charitable giving to different causes suggests that people in most countries give more to ingroup-organizations than to outgroup-organizations. For example, Rajan et al. (2009) found that only $0.2 \%$ of Canadians donated exclusively to international causes whereas $81.3 \%$ donated exclusively to domestic causes and $6.4 \%$ donated both internationally and domestically. Similarly, Micklewright \& Schnepf (2009) found that most of the $10.4 \%$ donating to international causes also donated to domestic causes in the UK (see also Casale \& Baumann, 2013). Sweden might however be an exception when it comes to charitable giving (van Leeuwen \& Wiepking, 2012; Vamstad, 2015). For example, Vamstad and von Essen (2012) showed that 
Swedes are more likely to donate to national campaigns focusing on outgroup victims (e.g. disaster relief, famine and wars) than campaigns focusing on ingroup victims (e.g. disease research and disabilities). The authors attributed this pattern to the idea that Swedish people perceive the extensive tax-financed welfare system in Sweden as responsible for taking care of domestic problems but not as much for taking care of international problems.

In the current study, donation behavior was measured by letting all participants first answer whether or not they had donated money to any charitable organization during the past year, and if so, to which organization(s), and how much money.

\section{How are donations to charitable organizations and helping intentions toward begging EU- migrants related to each other?}

The main aim of this paper is to investigate the relation between two kinds of prosocial behavior - helping begging EU-migrants and donating money to charitable organizations. Based on the existing literature, it is possible to find support for a number of mutually inconsistent possibilities.

The first possibility is that helping beggars and donating money to charitable organizations are negatively related. It is reasonable to argue that there are limits on how much resources people are prepared to spend on others, and money given to beggars can therefore crowd out donations to charitable organizations (or the other way around). A similar prediction comes from the psychological theories of moral licensing and moral compensation (Zhong, Liljenquist \& Cain, 2009; Sachdeva, Iliev \& Medin, 2009). A person engaging in moral licensing could argue that because she is currently donating generously to several organizations, she has no obligation to also help beggars. Likewise, a person engaging in moral compensation (or moral cleansing) 
might experience feelings of guilt after ignoring several begging EU-migrants, and decide to donate to a charitable organization in order to relieve the guilt.

The second possibility is that helping beggars and donating money to charitable organizations are positively related. One can easily argue that helping begging EU-migrants and donations to charitable organizations both are consequences of having a "helpful personality" (Rushton, Chrisjohn \& Fekken, 1981; Batson et al., 1986), and this is supported by the finding that donating money and donating time are generally positively related (Brown and Lankford, 1992; Apinunmahakul et al., 2009). There are many individual differences between humans and many of these differences are intimately connected to prosocial behavior. Some of these differences are of demographic nature (e.g. sex, age, education, socioeconomic status; see Bekkers \& Wiepking, 2011 and Wiepking \& Bekkers, 2012 for reviews), whereas others are related to affective dispositions (e.g. empathy, Davis, Luce \& Kraus, 1994; and guilt, Leith \& Baumeister, 1998). There are even psychological scales designed to measure trait empathy or trait helpfulness (e.g. Davis, 1983; Konrath, Penner et al., 1995; O'Brien \& Hsing, 2010), and because both helping beggars and donating money to organizations are clear examples of helping behavior, they should both be positively related to any dispositional measure of helpfulness and to each other.

A third possibility emerges from the common distinction between ingroups and outgroups (e.g. Brewer 1999), and the fact that the way we treat our fellow ingroup-members does not always predict how we treat outgroup-members (e.g. Stürmer \& Snyder, 2010). According to this "group-identity hypothesis" the relation between helping beggars and donating to charitable organizations should vary as a function of which type of charitable organization one donates to. Different persons tend to support different charitable organizations because different charitable organizations focus on very different causes and on very different types of victims. For example, 
the father of a disabled child will likely be more motivated to support organizations focusing on children with disabilities whereas a woman who works as a physician will be more motivated to support organizations focusing on research or on organizations providing basic health in developing countries (c.f. the friend of victim effect, Small \& Simonsohn, 2008; Srnka, Grohs \& Eckler, 2003; Breeze, 2013). Wiepking (2010) found that those with high socioeconomic status gave less to general charities but more to fine art and culture compared to low socioeconomic status donors, and a survey about Swedish charitable giving (Swedbank Robur, 2011), showed that older people donated more to research about illnesses whereas donations to child-cancer was highest for people in the age span 30-44 years (when people usually have children). Possibly, the type of organization a person supports could tell us more about her/him, than merely the likelihood and magnitude of donations. Although one could argue that begging EU-migrants belong to the ingroup because they are physically close and visible, we suggest that most Swedes perceive begging EU-migrants as outgroup-members as they speak a different language, have different customs and because they do not contribute to the Swedish welfare system by paying taxes, which means that they are not included in the traditional social contract. The 'groupidentity hypothesis' would receive support if helping intentions toward beggars were positively correlated with donation behavior toward outgroup-charities but uncorrelated or even negatively correlated with donation behavior toward ingroup-charities.

An obvious problem is that classifying different organizations as outgroup-charities or ingroup-charities can be difficult. For example, The Swedish Red Cross and Save the Children have projects focusing on helping suffering people in Sweden but most of their projects focus on helping victims in developing countries. Likewise, donations given to the Swedish Cancer Society goes primarily to funding medical research for detecting and curing cancer. This research 
will benefit not only cancer patients in Sweden but also in other countries. In order to base our classification on something more than our own intuitions, we conducted an "organization classification study", in which a separate sample of Swedes rated to which extent some of the most well-known and recognized Swedish charity organizations focus their effort primarily on the environment, on out-group victims or on ingroup-victims. The results of this study were used for classifying the charitable organizations in the main study.

Also, previous studies have used socio-demographic variables as predictors of outgroup- and ingroup-focused helping. For example, people with a higher education are more likely to donate to internationally-focused causes but not to medical research or animal welfare in Canada (Micklewright \& Scnepf, 2009). Education, religiosity, and being born abroad predicted a higher fraction of donations going to international causes among US and Austrian respondents (Casale \& Baumann, 2013; Neumar \& Handy, 2017). Rajan et al. (2009) found similar results and found also that women contributed more to international charities whereas Wiepking (2010) found that persons who leaned left politically supported international relief comparably more that those who leaned right. In light of these findings, the current study controlled for participants sex, age, education, income, religiosity, as well as political inclination when investigating the relation between helping intention toward beggars and donations to outgroup- and ingroup-charities. 


\section{Organization classification study}

80 Swedish participants (convenience sample) conducted a survey either online or using paper and pen. Data collection took place in early 2016. Participants rated several of the most wellknown charitable organizations in Sweden on a number of dimensions. Of interest in this paper is whether or not different organizations were perceived as primarily helping outgroup victims, ingroup victims or primarily protecting the environment/animals.

Participants were presented with a list of Swedish charitable organizations and were asked, after each organization, to first indicate to what extent they perceived the organization to focus on environmental issues and on issues relating to animals by writing down a number between 0 (no environmental focus whatsoever) and 5 (strong environmental focus). Participants could also respond that they were not familiar with the given organization. Four of the included organizations had mean scores over 4.5, making them typical environment-organizations. All other organizations had scores significantly $(p<.05)$ below the theoretical mean of 2.5. (see left column in Table 1).

Next, participants were asked to indicate to what extent they perceived the organizations to focus primarily on Swedish victims or on Non-Swedish victims by writing down a number between 0 (exclusive focus on Swedish victims) and 5 (exclusive focus on non-Swedish victims) after each organization. Ten organizations had mean scores significantly above the theoretical mean of 2.5 and were consequently classified as outgroup-organizations. Ten organizations had mean scores significantly below 2.5 and were consequently classified as ingroup-organizations. Three of the remaining organizations were not significantly different from 2.5 (see Table 1). 
THE RELATION BETWEEN CHARITABLE DONATIONS AND HELPING BEGGARS

---Table 1 about here--- 


\section{Main Study Method}

The data in the main study were collected in November 2015, as a part of a broader survey intended to investigate Swedes' helping intentions, as well as attitudes, thoughts, and feelings towards begging EU-migrants in Sweden. The survey was administered with the help of CMA Research - an independent research firm with access to a large panel of participants making up a roughly representative sample of the Swedish population. In total, 1383 participants were recruited to participate in an online-survey. Participants were 18-75 years old and had previously signed up as participants for studies administered by CMA Research. The online-survey consisted of four separate parts that were filled out in a fixed order: Part 1: 21 items about participants' helping intentions towards begging EU-migrants; Part 2: 28 items about emotional reactions, thoughts and beliefs about begging EU-migrants; Part 3: 40 items about individual differences in moral intuitions and types of prosocial motivation; Part 4: 15 items tapping demographic differences. In this article, we focus on the relation between helping intentions toward begging EU-migrants (collected in Part 1) and donation behavior toward different types of charitable organizations (collected in Part 4). ${ }^{1}$ Our control variables (participants' sex, age, level of education, income, degree of religiosity, and political inclination) were also assessed in Part 4. The analyses include data from the 1050 participants $\left(49.6 \%\right.$ female, $M_{\text {age }}=52.10, S D=$ 14.90) who finished the full survey. This inclusion criterion was decided prior to any analyses.

\section{Included variables}

\section{Helping intention toward beggars (dependent variable)}

Participants' helping intentions toward begging EU-migrants were operationalized as the selfrated likelihood that they would, at any time during the coming 12 months, perform each of 21 
THE RELATION BETWEEN CHARITABLE DONATIONS AND HELPING BEGGARS

different prosocial acts that directly or indirectly benefit begging EU-migrants (see Table 2).

Participants responded to these questions in the very beginning of the survey. For each prosocial act, they responded on a Likert-scale ranging from 0 (I will definitely not do this) via 4 (I will maybe do this) to 8 (I will definitely do this).

---Table 2 about here---

\section{Donation behavior (independent variable)}

Information about participants' donation behavior was collected in Part 4 of the survey. Participants first responded to the question "Have you donated money to any charitable organization during the past year?" and responded YES, NO or DO NOT KNOW. Participants answering YES to this question (henceforth referred to as 'the donation question') were then asked which organization(s) they had donated money to during the past year. Participants were presented with 23 of the largest and most well-known charitable organizations in Sweden (see Table 1), and could mark any organization they had donated money to. Participants could also mark a box labeled "Other organization" and write the name of the organization(s) they had donated to, or refrain from specifying any organization. Participants who had answered YES on the donation question were then asked about approximately how much (in Swedish Kronor) they donated to charity each month.

Based on the results from the organization classification study, ten of the organizations were classified as outgroup-organizations, ten as ingroup-organizations, and four as environmental- 
organizations (see Table 1). Three of the listed organizations could not be classified based on the results in the organization classification study, and the City Mission organization was not classified because this organization has its primary focus on helping homeless people including begging EU-migrants, which means that donations to this organization could be seen as indirect helping toward beggars.

For each participant, we created three dichotomous dummy variables illustrating whether they had donated to any outgroup organization, to any ingroup organization, and to any environmental organization during the past year $(0=\mathrm{NO}, 1=$ YES for each). To complement this, we also created three continuous variables measuring the number of classified outgroup organizations (possible range 0-10), ingroup organizations (possible range 0-10), and environmental organizations (possible range 0-4) each participant had donated to during the past year.

\section{Control variables}

Participants' sex $(0=$ male, $1=$ female $)$ and current age $(18-75$ years old $)$ were assessed before starting the survey. Level of education and income were measured in Part 4 of the survey. Participants filled in their highest level of education $(1=$ did not complete junior high school, $2=$ completed junior high school, $3=$ completed high school, $4=$ took courses in college/university, $5=$ completed degree on college/university $)$, and their monthly income $(1=8000$ SEK or less, 2 $=8001-17000 \mathrm{SEK}, 3=17001-25000 \mathrm{SEK}, 4=25001-33000 \mathrm{SEK}, 5=33001-41000 \mathrm{SEK}, 6=$ 41001-50000 SEK, $7=50001-58000$ SEK, $8=58001$ SEK or more). Part 4 was also the place where participants rated their religiosity $(0=$ very non-religious, $9=$ very religious $)$ and their political orientation $(0=$ very far to the left, $9=$ very far to the right $)$ on ten-point Likert scales.

\section{Descriptive results.}


As can be seen in Table 2, most helping intention items were positively skewed and had a large number of zero-responses. This clearly shows that a large portion of the Swedish population believed that they would not help beggars in any way during the coming year. The only type of helping intention where the mean response was higher than the midpoint (i.e. $4=\mathrm{I}$ will maybe do this) was "smile and nod in a friendly way to a beggar". Despite this, the Cronbach's alpha for all 21 items was $\alpha=.95$ and no item decreased this score. The 21 items were therefore first standardized (in order to make all prosocial acts contribute equally much) and then aggregated into a single global helping intention variable. We did investigate different types of prosocial acts separately (e.g. direct vs. indirect help), but as the results were very similar, we report only the results from the global helping intention variable.

The right column in Table 1 shows the number of people (out of 1050) who reported donating to each of the 23 organizations included in the survey (and to the additional five organizations that were written down by participants and classified in the organization classification study). Table 1 also includes the Spearman rank-order correlations coefficients showing the relation between whether participants donated to each of the organizations $(0=\mathrm{NO}, 1=\mathrm{YES})$ and their helping intentions towards begging EU-migrants. A positive correlation indicate that a person donating to this organization reports more helping intentions toward beggars, than a person not donating to this organization.

\section{Regression analyses design}

In our main analyses, we used hierarchical regression analysis to investigate how charitable donations predict helping intentions toward begging EU-migrants when controlling for the effects of participants' sex, age, education, income, religiosity, and political inclination. Each of these variables had a roughly linear relation with the dependent variable. To make the helping 
intention variable more normally distributed (and more appropriate to include in regression analyses), we added 1 and then logarithmized the variable before using it as the dependent variable (Field, 2009). To test the robustness of results, all regressions reported are corrected with heteroscedasticity-consistent standard errors.

We organized the regression analysis so that the predictor variables were inserted in separate blocks. Block 1 included only the donation question (i.e. "Have you donated money to any charitable organization during the past year?"; $0=\mathrm{NO}, 1=\mathrm{YES})$. We added the donation amount in Block 2 (participants who responded NO on the donation question received the value zero). Donation amount was logarithmized before being entered into the model.

Block 3 was the block of main interest. In the first regression analysis (dichotomous predictor variables), we added three variables indicating whether participants had been donating to any of the classified outgroup organizations, any of the classified ingroup organization or to any of the classified environmental organization over the past year $(0=\mathrm{NO}, 1=$ YES on all three variables). A significant result on any of these predictors would indicate that the type of organization one donates to, predicts helping intentions toward beggars over and above the question whether one donates to charity at all, and the donation amount.

In the second regression analysis (continuous predictor variables), we replaced the three dichotomous variables with three variables indicating the number of classified outgroup organizations, the number of classified ingroup organizations and the number of classified environmental organizations participants reported donating to during the past year.

Block 4 to 6 consisted of control variables. Block 4 added participants sex $(0=$ Male, $1=$ Female) and participants current age. Block 5 added participant's level of completed education. 
We created two dummy variables to indicate low education (i.e. those who did not complete high school), high education (i.e. university/college experience) and used participants who finished high school, but who did not continue to university/collage, as the reference group. Block 5 also included current monthly income (on the aforementioned 8-point scale). Finally, in Block 6 we added participants self-rated level of religiosity and political inclination (where a higher score indicated a more right-wing orientation). Although we expected that several of these variables would predict helping intentions toward beggars in their own right, we also predicted that they would not fully account for the relation between donation behavior and helping intentions towards beggars.

\section{Results}

Bivariate correlations between all included variables are shown in Table 3.

---Table 3 about here---

\section{Regression analysis using the dichotomous predictor variables}

The adjusted $\mathrm{R}^{2}$ in Block 1 was 0.10 , which means donating (vs. not donating) to charity over the past year accounted for $10 \%$ of the variance in helping intentions toward beggars (see Table 4). Adding donation amount in Block 2 increased the $\mathrm{R}^{2}$ significantly $\left(\Delta \mathrm{R}^{2}=0.03\right)$ and both variables were significant positive predictors, which means that participants who donate more rather than less to charity have more helping intentions toward beggars. 
Adding the three dichotomous predictor variables in Block 3 increased the $\mathrm{R}^{2}$ significantly $\left(\Delta \mathrm{R}^{2}=0.05\right)$, which means that knowing the type of organization people donate to, helps us account for their helping intentions toward beggars over and above knowing whether they donated or not. Importantly, having donated to any outgroup organization $(B=0.16, \mathrm{SE} . B=$ $0.02, p<.001)$ and to a lesser extent to any environmental organization $(B=0.05, \mathrm{SE} . B=0.03, p$ $=.043$ ) predicted a higher intention to help beggars whereas having donated to any ingroup organizations predicted a slightly lower intention to help beggars $(B=-0.04$, SE. $B=0.02, p$ $=.038)$.

Adding participants' sex and age in Block 4 increased $R^{2}$ further $\left(\Delta R^{2}=0.03\right)$. Being female (vs. male) and younger (vs. older) positively predicted intention to help beggars. Adding these variables to the model made donations to environmental organizations and ingroup organizations non-significant predictors, but donations to outgroup organizations remained a robust predictor of helping intentions toward beggars.

We added participants' highest level of education completed and their monthly income in Block 5 and $\mathrm{R}^{2}$ increased further $\left(\Delta \mathrm{R}^{2}=0.03\right)$. Having a higher education than the reference group positively predicted intention to help beggars, but having a lower education did not predict intention to help beggars in either direction. Having a higher income negatively predicted intention to help beggars. Donations to outgroup organizations remained a robust predictor of helping intentions toward beggars when adding these variables to the model.

As expected when adding participants' self-rated religiosity and political inclination in Block $6, \mathrm{R}^{2}$ increased further $\left(\Delta \mathrm{R}^{2}=0.12\right)$. Being more religious positively predicted intention to help beggars whereas being more politically to the right (vs. to the left) negatively predicted intention to do so. Donation amount, current age, high education, religiosity, political inclination and- 
most importantly for the current paper - being an outgroup donor remained significant predictors even when all of the predictor variables were included.

\section{---Insert Table 4 here---}

\section{Regression analysis using the continuous predictor variables}

As Block 1 and 2 are identical to the analysis presented above, they are omitted here.

Adding the three continuous predictor variables in Block 3 increased the $\mathrm{R}^{2}$ significantly $\left(\Delta \mathrm{R}^{2}=\right.$ 0.06), which means that knowing the number of outgroup, ingroup, and environmental organizations the participants donated to, helps us account for their helping intentions toward beggars over and above knowing whether they donated or not. Importantly, the number of outgroup organizations donated to $(B=0.06$, SE. $B=0.01, p<.001)$ positively predicted intention to help beggars whereas the number of ingroup organizations donated to negatively predicted intention to help beggars $(B=-0.04$, SE. $B=0.01 p<.001)$. The number of environmental organizations donated to did not predict helping intentions $(B=0.02, \mathrm{SE} . B=0.02$, $p=.184)$

Adding participants' sex and age in Block 4 , increased $R^{2}$ further $\left(\Delta R^{2}=0.03\right)$. Being female (vs. male) and younger (vs. older) again positively predicted intention to help beggars. Unlike the previous analysis however, both the number of outgroup organizations (in the positive direction) and the number of ingroup organizations (in the negative direction) remained significant predictors of helping intentions toward beggars when these variables were added. 
We added participants' level of education and their monthly income in Block 5 and $\mathrm{R}^{2}$ increased further $\left(\Delta \mathrm{R}^{2}=0.03\right)$. As in the previous analysis, having a higher education than the reference group positively predicted intention to help beggars, but having a higher monthly income negatively predicted intention to help beggars. Both the number of outgroup organizations (positive direction) and the number of ingroup organizations (negative direction) donated to remained significant predictors of helping intentions toward beggars.

When adding participants' self-rated religiosity and political inclination in Block $6, \mathrm{R}^{2}$ increased further $\left(\Delta \mathrm{R}^{2}=0.13\right)$. Being more religious predicted intention to help beggars in the positive direction, whereas being more politically to the right predicted intention to do so in the negative direction. The number of outgroup organizations (positive direction, $p<.001$ ) and the number of ingroup organizations (negative direction, $p=.055$ ) donated to, remained significant or marginally significant predictors of helping intention toward beggars.

---Insert Table 5 here--- 


\section{Discussion}

Are Swedes who are donating money to charitable organizations more or less likely to help begging EU-migrants compared to those not donating? The results from this study suggest that although donation behavior to charitable organizations in general is positively related to helping intentions toward beggars, this pattern is driven almost exclusively by donations to outgrouporganizations.

The results do not support the idea that helping is a zero-sum game where an increase in one type of helping is accompanied by a decrease of another type of helping. Neither does it seem to be the case that donating to charitable organizations crowd out helping towards beggars. The results are more in line with the "helpful personality-hypothesis". People who are donating to charitable organizations are more likely to help beggars compared to people not doing so.

Nevertheless, the results also show there is a clear discrepancy between helpfulness toward outgroup victims and toward in-group victims, thus supporting the group-identity hypothesis.

Simply put, people who are donating to organizations focusing on outgroup-victims are much more likely to help beggars compared to people not doing so. On the other hand, people who are donating to organizations focusing on ingroup-victims are not more, and under some circumstances even slightly less likely, to give money to beggars compared to people not doing so. This is the main novel finding of this study.

This is important because it shows that the degree of outgroup helping cannot be inferred from the degree of ingroup helping and vice versa. Although rarely emphasized, deciding which charitable organization to support involves a moral dilemma and the response to this dilemma can express the donor's preferences, values and worldviews (Breeze, 2013). Arguably, a Swedish donor supporting primarily outgroup-organizations is likely to put a greater value on the severity 
of the situation (because there are more outgroup victims and they are usually suffering from more severe plight than ingroup-victims), or on the marginal utility principle (a fixed amount of resources increases the welfare more for those having less of the resource, e.g. Greene \& Baron, 2001). An average donor supporting primarily ingroup-organizations is likely to put a greater value on personal experiences (higher chance of personally knowing someone who can benefit from the donation, Small \& Simonsohn, 2008; Srnka et al., 2003) or on group-specific responsibilities (believing that you have a responsibility to help members of your own group but not a responsibility to help those outside of your group, Erlandsson, Björklund \& Bäckström, 2015; Baron, Ritov \& Greene, 2013).

Our findings pose interesting further questions whether the motivational factors behind helping outgroup victims (e.g. Syrian refugees or begging EU-migrants) are different from the motivational factors behind helping ingroup victims (e.g. Swedish people in need; Stürmer, Snyder \& Omoto, 2005; Stürmer et al., 2006; Stürmer \& Snyder, 2010)? Over several studies using different types of group-classifications, Stürmer and colleagues compared helping toward ingroup and outgroup individuals and found that while ingroup helping is motivated by automatic responses such as other-oriented empathy, outgroup helping is motivated by deliberative processes such as cost-benefit calculations or consideration of moral principles. In line with this, perceived personal responsibility was a better predictor for outgroup donations than for ingroup donation behavior in the study by Casale and Baumann (2013). If this conjecture is correct, appeals to empathy might elicit more donations if used by ingrouporganizations, but not so if used by outgroup-organizations or begging EU-migrants. Beggars (and outgroup-organizations) might even be better of appealing to more cognitive factors such as cost-benefit analyses or intrinsically held moral values, or possibly by trying to manipulate the 
boundaries of the perceived ingroup among donors (Gaertner et al., 1993). Experimental studies are surely needed to test these predictions.

Furthermore, perceived innocentness and perceived competence of the victim to help him- or herself are better predictors for outgroup-helping than for ingroup-helping (Stürmer \& Snyder, 2010). Although we have no data to support it, we believe that begging EU-migrants in Sweden are generally perceived by the Swedish public as more responsible for their plight than, for example, victims of a natural disaster, and less capable of helping themselves if given some initial help than, e.g. a well-educated Syrian refugee. If so, this could be an explanation of why helping beggars is one of the most "unpopular" charitable causes (Body \& Breeze, 2016).

A relevant concept when discussing individual differences in philanthropy within social sciences is social capital. According to Brown and Ferris (2007), social capital should be measured in terms of norms (i.e. a person's general trust in other people and the system), and networks (the number of associational ties the person has). When including both norms and networks in models predicting secular charitable giving and volunteering, the direct influences of education (human capital) and religiosity are reduced (Brown \& Ferris, 2007). Also, Putnam (2000) differentiates between bonding social capital (a very strong connection and trust toward a relatively small ingroup) and bridging social capital (a slightly less strong connection to a relatively large ingroup). In relation to this study, one could argue that those who value strong ties and loyalty within small groups are more likely to be ingroup-donors whereas those who value a wide circle of inclusion are more likely to be outgroup-donors.

Relatedly, the activities that outgroup organizations and ingroup organizations engage in are admittedly rarely directly comparable. The types of problems that most outgroup organizations are trying to remedy in poor countries (by providing basic welfare and catastrophe aid) have 
since many years been expected to be taken care of by the welfare state in Sweden. In contrast, most problems that ingroup organizations are trying to remedy have never been expected to be fully taken care of by the welfare state. One explanation of the results could thus be that outgroup donors focus primarily on human rights whereas ingroup donors focus primarily on social rights. Human rights are unconditional whereas social rights are conditional in the sense that in order to be entitled to welfare services one must be part of the social contract (e.g. be a tax-paying citizen). According to this explanation, it might not only be the "outgroup-aspect" of the beggars that discourage people to help them, but rather that the people asking for help are not part of the traditional Swedish social contract.

\section{Limitations}

An obvious limitation of this study is that both donations to charitable organizations and helping intentions toward beggars were self-reported. Donation behavior were rated retrospectively whereas helping toward beggars was rated prospectively. Participants can obviously overestimate (or underestimate) their prosociality with both types of ratings.

Also, as a majority of the ingroup-organizations focused on medical research, it could be argued that the focal point among those who donate to e.g. the Swedish Cancer society is that they focus on research that has the potential to benefit many persons in the future (not that they help Swedes). Importantly, we based our classification of organizations on the results from the organization classification study where a separate group of participants rated to what extent they perceived that the organizations focused primarily on Swedish ingroup-victims or on nonSwedish outgroup victims. This classification is neither based on any "objective" criterion nor on how the organizations perceive their own work, but rather on how the Swedish public perceive 
THE RELATION BETWEEN CHARITABLE DONATIONS AND HELPING BEGGARS

different charity organizations, and perceived characteristics of recipients seem to matter more than objective characteristics (van Leeuwen \& Wiepking, 2012).

It should also be mentioned that the data was collected in November 2015. Although the general population had very diverse opinions at that time, the general opinion among experts was that organized trafficking of beggars did not exist in Sweden then (e.g. Djuve, 2015; Valfridsson, 2016). More recently however, there have been convicting sentences of trafficking where poor Bulgarians have been tricked to come to Sweden in order to beg in order to earn money for criminals, while living under slave-like conditions (The Local, 2017). Although the vast majority of EU-migrants in Sweden are begging to earn money for themselves and for their families, recent polls suggest that these events made Swedes in general even less prosocial towards beggars (Sveriges Radio, 2018).

A final caveat is it that all authors of this article are psychologists, meaning that we might tend to interpret the obtained findings relatively more from the "micro" level (e.g. as individual differences in values and helping behavior), and less from the "macro" level (e.g. as a result of the Swedish welfare system). We surely believe that both levels of explanation are important and hope that the empirical findings will be useful also for those who prefer macro level explanations (e.g. scholars in sociology and political science).

\section{Implications and conclusion}

The main theoretical implication of this study is that researchers conducting empirical studies on donation behavior would benefit from measuring donation behavior toward outgroup-causes and ingroup-causes separately. This is because the results of both the present study and others (e.g. Casale \& Baumann, 2013; Micklewright \& Schnepf, 2009) show that several 
sociodemographic, psychological, and behavioral factors that strongly predict outgrouporganization donations do not predict ingroup-organization donations at all.

There are also practical implications for charitable organizations. By understanding more about the attitudes and behavior of people who are (and are not) donating to a given organization, it is possible to create more efficient fund-raising campaigns (Srnka et al., 2003; Rajan et al., 2009). Our research shows that people donating to outgroup-organizations have much more positive attitudes toward beggars than those not donating to any charitable organization. On the contrary, people donating exclusively to ingroup-organizations are just as negative towards beggars as those not donating to any charity. This information is relevant for both types of charity organizations. For example, if an outgroup-organization would start up a campaign with the explicit goal of helping beggars in Sweden, this at least has the potential to work well because many people donating to them already have a relatively sympathetic view of begging EU-migrants. On the other hand, if an ingroup-organization would start up a campaign with the goal of helping poor EU-migrants, this might backfire because the values expressed by the organization would then be in conflict with the values of many of its supporters.

To conclude, this study shows that at least in Sweden, donations to outgroup-organizations but not donations to ingroup-organization predict higher helping intentions toward begging EUmigrants compared to non-donors. This suggests that knowing what type of organization or cause a person donates to tells us more about his or her values and worldviews than merely knowing whether s/he donates or not. 


\section{Endnotes}

1. The survey was conducted as part of a broader research project about attitudes and behaviors toward beggars among Swedish adults. In order to increase comprehensibility and readability, we do not present results from the whole survey in a single paper. Specifically, the current paper focuses on the relation between donation routines and helping intentions toward street-beggars. Two other papers partially based on data from the same survey focus on individual differences in moral intuitions and its relation to different forms of helping (Nilsson, Erlandsson \& Västfjäll, 2016), and on which kind of feelings, thoughts, and beliefs toward beggars best predict helping intentions toward them (Jørgensen \& Erlandsson, manuscript in preparation). The full survey (material and raw data) can be obtained by the first author upon request. 
THE RELATION BETWEEN CHARITABLE DONATIONS AND HELPING BEGGARS

\section{References}

Apinunmahakul, A., Barham, V., \& Devlin, R. A. (2009). Charitable giving, volunteering, and the paid labor market. Nonprofit and Voluntary Sector Quarterly, 38(1), 77-94.

Baron, J., Ritov, I., \& Greene, J. D. (2013). The duty to support nationalistic policies. Journal of Behavioral Decision Making, 26(2), 128-138.

Batson, C. D., Bolen, M. H., Cross, J. A., \& Neuringer-Benefiel, H. E. (1986). Where is the altruism in the altruistic personality? Journal of Personality and Social Psychology, $50(1), 212-220$.

Bekkers, R., \& Wiepking, P. (2011). Who gives? A literature review of predictors of charitable giving part one: religion, education, age and socialization. Voluntary Sector Review, 2(3), 337-365.

Body, A., \& Breeze, B. (2016). What are 'unpopular causes' and how can they achieve fundraising success? International Journal of Nonprofit and Voluntary Sector Marketing, 21(1), 57-70.

Boeryd, K. (2014). Tiggeri: En jämförelse mellan svensk, dansk och norsk lagstiftning. Lund University.

Breeze, B. (2013). How donors choose charities: the role of personal taste and experiences in giving decisions. Voluntary Sector Review, 4(2), 165-183.

Brewer, M. B. (1999). The psychology of prejudice: Ingroup love and outgroup hate? Journal of social issues, 55(3), 429-444.

Brown, E., \& Ferris, J. M. (2007). Social capital and philanthropy: An analysis of the impact of social capital on individual giving and volunteering. Nonprofit and Voluntary Sector Quarterly, 36(1), 85-99. 
THE RELATION BETWEEN CHARITABLE DONATIONS AND HELPING BEGGARS

Brown, E., \& Lankford, H. (1992). Gifts of money and gifts of time estimating the effects of tax prices and available time. Journal of Public Economics, 47(3), 321-341.

Casale, D., \& Baumann, A. (2015). Who gives to international causes? A sociodemographic analysis of U.S. donors. Nonprofit and Voluntary Sector Quarterly, 44(1), 98-122.

Davis, M. H. (1983). Measuring individual differences in empathy: Evidence for a multidimensional approach. Journal of Personality and Social Psychology, 44(1), 113 126.

Davis, M. H., Luce, C., \& Kraus, S. J. (1994). The heritability of characteristics associated with dispositional empathy. Journal of Personality, 62(3), 369-391.

Djuve, A. B., Friberg, J. H., Tyldum, G., \& Zhang, H. (2015). When poverty meets affluence: Migrants from Romania on the streets of the Scandinavian capitals. Retrieved from https://www.fafo.no/images/pub/2015/954-innmat-trykk.pdf

Dustmann, C., Fasani, F., Frattini, T., Minale, L., \& Schönberg, U. (2016). On the Economics and Politics of Refugee Migration. CESifo Working Paper, (6111).

Erlandsson, A., Björklund, F., \& Bäckström, M. (2015). Emotional reactions, perceived impact and perceived responsibility mediate the identifiable victim effect, proportion dominance effect and in-group effect respectively. Organizational Behavior and Human Decision Processes, 127(0), 1-14.

Field, A. (2009). Discovering statistics using SPSS: Sage publications.

FRII. (2018). Insamlingen i siffror. Retrieved from https://www.frii.se/kunskap/statistik/

Gaertner, S. L., Dovidio, J. F., Anastasio, P. A., Bachman, B. A., \& Rust, M. C. (1993). The common ingroup identity model: Recategorization and the reduction of intergroup bias. European Review of Social Psychology, 4(1), 1-26. 
THE RELATION BETWEEN CHARITABLE DONATIONS AND HELPING BEGGARS

Goldberg, T. L. (1995). Altruism towards panhandlers: Who gives? Human Nature, 6(1), 79-89.

Greene, J., \& Baron, J. (2001). Intuitions about declining marginal utility. Journal of Behavioral Decision Making, 14(3), 243-255.

Holmqvist, A., \& Karlsson, P. (2015, April 3rd). SVERIGE TYCKER: Fler vill ha tiggeriförbud. Aftonbladet. Retrieved from http://www.aftonbladet.se/nyheter/article20562767.ab.

Konrath, S. H., O'Brien, E. H., \& Hsing, C. (2010). Changes in dispositional empathy in american college students over time: A meta-analysis. Personality and Social Psychology Review.

Leith, K. P., \& Baumeister, R. F. (1998). Empathy, shame, guilt, and narratives of interpersonal conflicts: Guilt-prone people are better at perspective taking. Journal of Personality, $66(1), 1-37$.

Lockard, J., McDonald, L., Clifford, D., \& Martinez, R. (1976). Panhandling: Sharing of resources. Science, 191(4225), 406-408.

Mella, O., Ahmadi, F., \& Palm, I. (2013). Mångfaldsbarometern 2013. Retrieved from https://www.hig.se/download/18.4d5c738013f2afde56fb8fb/1381770808240/M\%C3\%A5 ngfaldsbarometern+2013+-+rapport.pdf:

Micklewright, J., \& Schnepf, S. V. (2009). Who gives charitable donations for overseas development? Journal of Social Policy, 38(02), 317-341.

Neumayr, M., \& Handy, F. (2017). Charitable giving: What influences donors' choice among different causes? VOLUNTAS: International Journal of Voluntary and Nonprofit Organizations, 1-29. 
THE RELATION BETWEEN CHARITABLE DONATIONS AND HELPING BEGGARS

Nilsson, A., Erlandsson, A., \& Västfjäll, D. (2016). The congruency between moral foundations and intentions to donate, self-reported donations, and actual donations to charity. Journal of Research in Personality.

Penner, L. A., Fritzsche, B. A., Craiger, J. P., \& Freifeld, T. R. (1995). Measuring the prosocial personality. Advances in Personality Assessment, 10, 147-163.

Putnam, R. D. (2000). Bowling alone: America's declining social capital Culture and politics (pp. 223-234): Springer.

Rajan, S. S., Pink, G. H., \& Dow, W. H. (2009). Sociodemographic and personality characteristics of Canadian donors contributing to international charity. Nonprofit and Voluntary Sector Quarterly, 38(3), 413-440.

Rushton, P. J., Chrisjohn, R. D., \& Fekken, C. G. (1981). The altruistic personality and the selfreport altruism scale. Personality and Individual Differences, 2(4), 293-302.

Sachdeva, S., Iliev, R., \& Medin, D. L. (2009). Sinning saints and saintly sinners: The paradox of moral self-regulation. Psychological Science, 20(4), 523-528.

Small, D. A., \& Simonsohn, U. (2008). Friends of victims: Personal experience and prosocial behavior. Journal of Consumer Research, 35(3), 532-542.

Socialstryrelsen. (2013). Hemlöshet bland utrikesfödda personer utan permanent uppehållstillstånd i Sverige. Retrieved from http://www.socialstyrelsen.se/Lists/Artikelkatalog/Attachments/19052/2013-5-3.pdf.

Srnka, K. J., Grohs, R., \& Eckler, I. (2003). Increasing fundraising efficiency by segmenting donors. Australasian Marketing Journal (AMJ), 11(1), 70-86. 
THE RELATION BETWEEN CHARITABLE DONATIONS AND HELPING BEGGARS

Stürmer, S., \& Snyder, M. (2010). Helping "Us" versus "Them": Towards a group-level theory of helping and altruism within and across group boundaries. In S. Stürmer \& M. Snyder (Eds.), The Psychology of Prosocial Behavior. Chichester, UK: Wiley-Blackwell.

Stürmer, S., Snyder, M., Kropp, A., \& Siem, B. (2006). Empathy-motivated helping: The moderating role of group membership. Personality and Social Psychology Bulletin, $32(7), 943-956$.

Stürmer, S., Snyder, M., \& Omoto, A. M. (2005). Prosocial emotions and helping: The moderating role of group membership. Journal of Personality and Social Psychology, $88(3), 532-546$

Sveriges Radio. (April 16th, 2018). Majoritet vill ha tiggeriförbud. Retrieved from https://sverigesradio.se/sida/artikel.aspx?programid=83\&artikel=6930578

Swedbank Robur. (2011). Undersökning om svenska folkets attityder och givande till ideella hjälporganisationer, synen på ideella fonder samt inställningen till företagens samhällsoch miljöansvar. Argument AB.

The Local (2017). Two men sentenced in Sweden for human trafficking. Retrieved from https://www.thelocal.se/20171122/two-men-sentenced-in-sweden-for-human-trafficking Valfridsson, M. (2016). Framtid sökes - Slutredovisning från den nationella samordnaren för utsatta EU-medborgare. (SOU 2016:6). Retrieved from http://www.regeringen.se/rattsdokument/statens-offentliga-utredningar/2016/02/sou$\underline{20166 / .}$

Vamstad, J. (2015). Det folkliga givandet: om gåvor till välgörande ändamål i Sverige: Ersta Sköndal högskola. 
THE RELATION BETWEEN CHARITABLE DONATIONS AND HELPING BEGGARS

Vamstad, J., \& von Essen, J. (2012). Charitable giving in a universal welfare state-Charity and social rights in Sweden. Nonprofit and Voluntary Sector Quarterly.

van Leeuwen, M. H. D., \& Wiepking, P. (2013). National campaigns for charitable causes: A literature review. Nonprofit and Voluntary Sector Quarterly, 42(2), 219-240.

Wiepking, P. (2010). Democrats support international relief and the upper class donates to art? How opportunity, incentives and confidence affect donations to different types of charitable organizations. Social Science Research, 39(6), 1073-1087.

Wiepking, P., \& Bekkers, R. (2012). Who gives? A literature review of predictors of charitable giving. Part Two: Gender, family composition and income. Voluntary Sector Review, $3(2), 217-245$.

Wijkström, F. (2011). "Charity Speak and Business Talk" The On-Going (Re)hybridization of Civil Society. In F. Wijkström \& A. Zimmer (Eds.), Nordic Civil Society at a CrossRoads: Transforming the Popular Movement Tradition (1 ed., pp. 25-55). Baden-Baden: Nomos Verlagsgesellschaft mbH \& Co. KG.

Zhong, C.-B., Liljenquist, K. A., \& Cain, D. M. (2009). Moral self-regulation: Licensing \& compensation. In D. De Cremer (Ed.), Psychological perspectives on ethical behavior and decision making (pp. 75-89). Charlotte, NC: Information Age. 


\section{Bibliographical paragraphs}

$\mathrm{AE}$ is a postdoctoral researcher at Linköping University. He researches about decision making in helping situations and underlying mechanisms of helping.

$\mathrm{AN}$ is an assistant professor at Lund University. He researches about individual differences in values and worldviews.

GT is an associate professor at Linköping University. He researches about e.g. prosocial behavior from a behavioral and neuroeconomical perspective.

DA is a statistician.

DV is a professor in cognitive psychology at Linköping University. He researches on how emotions influence cognitions, perceptions and decision making. 


\section{Tables}

Table 1

Charitable organizations included in the main study. "*” denotes that the organization was not included in the list in the main study but written down by participants. Correlations with helping intention toward street-beggars are not reported for organizations with less than 30 donors.

\begin{tabular}{cc} 
Organization Classification Study \\
\hline $\begin{array}{c}\text { Environmental } \\
\text { focus [0-5] }\end{array}$ & Focus on \\
& Ingroup [0]/ \\
& Outgroup [5]
\end{tabular}

\begin{tabular}{cc} 
Main study \\
\hline $\begin{array}{c}\text { Number of donors } \\
\text { (out of 1050) }\end{array}$ & $\begin{array}{c}\text { Rank-order correlation } \\
\text { coefficients showing the } \\
\text { relation between donations to } \\
\text { each of the organizations } \\
(0=\text { No donation, } \\
1=\text { donation) and general } \\
\text { helping intention toward street- }\end{array}$
\end{tabular}

UNICEF Sweden

Doctors without Borders

Save the Children

SOS Children's villages

Swedish Red Cross

UNHCR

Plan Sweden

Radio Aid

IM - Swedish Development Partner

Amnesty International*

\section{Outgroup-organizations}

0.4

$\begin{array}{ll}0.40(0.91) & 3.28(1.33) \\ 0.40(0.99) & 4.11(0.96) \\ 0.29(0.78) & 3.55(1.07) \\ 0.47(1.06) & 4.40(0.70) \\ 0.58(1.04) & 3.37(1.02) \\ 0.51(0.99) & 3.63(1.44) \\ 0.62(1.15) & 2.96(1.62) \\ 1.40(1.67) & 3.33(1.10) \\ 0.72(1.32) & 2.98(1.25) \\ 0.90(1.57) & 3.87(1.04)\end{array}$

\begin{tabular}{cc} 
& beggars \\
\hline 138 & .155 \\
230 & .148 \\
185 & .116 \\
100 & .111 \\
177 & .145 \\
76 & .195 \\
39 & .075 \\
107 & .203 \\
14 & \\
12 &
\end{tabular}

Swedish Cancer society

Swedish Childhood

cancer foundation

$0.09(0.33) \quad 1.65(1.37)$

$0.13(0.64)$

$1.53(1.19)$

$0.09(0.60)$

$1.64(1.38)$

foundation

$0.11(0.52)$

$1.53(1.05)$

The Brain foundation

Swedish Make a Wish foundation

The Salvation Army

$0.17(0.57)$

$1.39(1.39)$

0.59 (1.27)

$1.94(1.08)$

2.12 (1.92)

$1.66(1.44)$

$0.29(1.06)$

$1.43(1.14)$

$0.08(0.40)$

$1.17(1.03)$

$0.28(0.94)$

$1.37(1.05)$

Foundation*

The Swedish Association of Hard

of Hearing People*

Swedish Children's Heart

Association*

\section{3}

166

$-.055$

$-.035$

131

$-.073$

31

.018

$33-.026$

$36-.038$

44

$-.052$

\section{3}

6

1

\section{Environment-organizations}

WWF

$4.62(1.08)$

99

.057

The Swedish Society for Nature

Conservation

$4.73(0.88)$

55

.085

Greenpeace

$4.65(0.94)$

51

.072

Animal Rights Sweden*

$4.66(1.12)$

4

\section{Unclassified organizations}

The Swedish Church

ERIKS Development Partner

$\begin{array}{lll}0.87(1.21) & 2.36(1.12) & 7 \\ 0.43(1.04) & 2.38(1.20) & 5 \\ 0.25(0.66) & 2.57(1.39) & 1 \\ 0.36(0.94) & 1.72(1.22) & 5\end{array}$

.082

50

.083

The Children's fund

10

The City Mission ${ }^{1}$

59

.143

${ }^{1}$ The City Mission was not classified as their explicit aim is to help homeless people in Sweden (including begging EU-migrants) meaning that support to them can be seen as indirect monetary helping to begging EU-migrants. 
Table 2

The 21 included prosocial acts. Participants rated the likelihood that they would perform each act anytime during the coming 12 months. $(0=$ I will definitely not do this $)$ via $(4=$ I will maybe do this $)$ to $(8=$ I will definitely do this $)$.

Item

1. Give coins to a begging EU-migrant at your local grocery store

2. Give bills to a begging EU-migrant at your local grocery store

3. Give a bag of empty cans to a begging EU-migrant at your local grocery store

4. Give food or beverage to a begging EU-migrant at your local grocery store

5. Give clothes, shoes or blankets to a begging EU-migrant at your local grocery store

6. Give toys, kitchen appliances or something else useful to a begging

EU-migrant at your local grocery store

7. Smile and nod friendly to a begging EU-migrant at your local grocery store

8. Initiate a friendly conversation with a begging EU-migrant at your

local grocery store

9. Visit a camp where begging EU-migrants live in order to talk friendly with them.

10. Donate money to an organization who is arranging soup kitchens for begging EU-migrants

11. Donate money to an organization who is helping begging EU-

migrants obtain health- and dental-care in Sweden

12. Donate money to an organization who is arranging shelters and opportunities to shower for begging EU-migrants in Sweden

13. Donate clothes, shoes or blankets to an organization helping EUmigrants in Sweden.

14. Donate toys, kitchen appliances or something else useful to an organization helping EU-migrants in Sweden.

15. Donate durable food or beverage to an organization helping EUmigrants in Sweden.

16. Signing a name list in favor of keeping begging legal in Sweden. 17. Volunteering for an organization collecting and distributing clothes, shoes and blankets to begging EU-migrants in Sweden

18. Engage actively in an organization working politically to improve the situation for begging EU-migrants in Sweden

19. Donating money to an organization that focuses on helping poor EUcitizens in their home countries.

20. Supporting a political suggestion which would mean that you must pay a higher tax, and that Sweden increases their foreign aid to poor EUcitizens in their home countries.

21. Volunteering for an organization working politically to improve the situation for poor EU-citizens in their home countries.

\begin{tabular}{|c|c|c|}
\hline $\begin{array}{l}\text { Mean (SD) } \\
{[0-8 \text { scale] }}\end{array}$ & $\begin{array}{l}\text { Proportion } \\
\text { answering zero }\end{array}$ & $\begin{array}{l}\text { Proportion } \\
\text { answering } \geq 4\end{array}$ \\
\hline $2.32(3.05)$ & $51.2 \%$ & $31.8 \%$ \\
\hline $1.50(2.51)$ & $63.7 \%$ & $21.2 \%$ \\
\hline $1.11(2.03)$ & $66.8 \%$ & $15.9 \%$ \\
\hline $1.38(2.14)$ & $57.9 \%$ & $19.0 \%$ \\
\hline $1.04(1.78)$ & $63.0 \%$ & $13.0 \%$ \\
\hline $0.71(1.41)$ & $70.6 \%$ & $7.5 \%$ \\
\hline $5.32(3.01)$ & $13.5 \%$ & $74.2 \%$ \\
\hline $1.74(2.19)$ & $47.5 \%$ & $23.7 \%$ \\
\hline $0.54(1.26)$ & $76.8 \%$ & $5.0 \%$ \\
\hline $2.00(2.38)$ & $46.9 \%$ & $32.5 \%$ \\
\hline $1.69(2.23)$ & $51.9 \%$ & $25.8 \%$ \\
\hline $1.85(2.31)$ & $48.6 \%$ & $29.6 \%$ \\
\hline $2.26(2.46)$ & $42.1 \%$ & $36.6 \%$ \\
\hline $1.84(2.26)$ & $47.8 \%$ & $29.1 \%$ \\
\hline $1.25(1.89)$ & $58.4 \%$ & $18.7 \%$ \\
\hline $1.45(2.38)$ & $64.4 \%$ & $21.9 \%$ \\
\hline $0.71(1.44)$ & $71.6 \%$ & $8.1 \%$ \\
\hline $0.62(1.40)$ & $75.5 \%$ & $6.7 \%$ \\
\hline $3.09(2.58)$ & $28.2 \%$ & $51.6 \%$ \\
\hline $1.97(2.50)$ & $49.4 \%$ & $30.1 \%$ \\
\hline $0.81(1.53)$ & $68.5 \%$ & $9.0 \%$ \\
\hline
\end{tabular}


Table 3

Bivariate correlation coefficients between the included variables in the main study. Pearson correlations are displayed when both variables are continuous. Spearman rank-order correlations are displayed when one or both variables are categorical (Variables 1,3,5, and 9)

\begin{tabular}{|c|c|c|c|c|c|c|c|c|c|c|c|c|c|c|c|}
\hline & & 1 & 2 & 3 & 4 & 5 & 6 & 7 & 8 & 9 & 10 & 11 & 12 & 13 & 14 \\
\hline 1. & $\begin{array}{l}\text { Helping decision } \\
\text { question (NO/YES) }\end{array}$ & 1 & & & & & & & & & & & & & \\
\hline 2. & $\begin{array}{l}\text { Donation amount } \\
(\log )\end{array}$ & $.67 * * *$ & 1 & & & & & & & & & & & & \\
\hline 3. & $\begin{array}{l}\text { Donation to } \\
\text { outgroup-org } \\
\text { (NO/YES) }\end{array}$ & $.62 * * *$ & $.61 * * *$ & 1 & & & & & & & & & & & \\
\hline 4. & $\begin{array}{l}\text { Number of } \\
\text { outgroup-org }\end{array}$ & $.57 * * *$ & $.55^{* * *}$ & $.92 * * *$ & 1 & & & & & & & & & & \\
\hline 5. & $\begin{array}{l}\text { Donation to } \\
\text { ingroup-org } \\
\text { (NO/YES) }\end{array}$ & $.50 * * *$ & $.35 * * *$ & $.29 * * *$ & $.28 * * *$ & 1 & & & & & & & & & \\
\hline 6. & $\begin{array}{l}\text { Number of ingroup- } \\
\text { org }\end{array}$ & $.48 * * *$ & $.37 * * *$ & $.29 * * *$ & $.31 * * *$ & $.96^{* * *}$ & 1 & & & & & & & & \\
\hline 7. & $\begin{array}{l}\text { Donation to env. } \\
\text { Org (NO/YES) }\end{array}$ & $.24 * * *$ & $.31 * * *$ & $.21 * * *$ & $.22 * * *$ & $.15^{* * *}$ & $.16^{* * *}$ & 1 & & & & & & & \\
\hline 8. & Number of env. org & $.24 * * *$ & $.28 * * *$ & $.21 * * *$ & $.23 * * *$ & $.14 * * *$ & $.16^{* * *}$ & $.99 * * *$ & 1 & & & & & & \\
\hline & Female sex & $.08^{*}$ & $.08^{*}$ & $.10^{* *}$ & $.10^{* *}$ & .05 & .06 & .05 & .06 & 1 & & & & & \\
\hline 10. & Age & .03 & $.11 * * *$ & .05 & .01 & $.15^{* * *}$ & $.19 * * *$ & $-.07 *$ & $-.07 *$ & $-.06^{*}$ & 1 & & & & \\
\hline & Education & $.12 * * *$ & $.09 * *$ & $.17 * * *$ & $.18 * * *$ & -.01 & -.03 & $.08^{*}$ & $.08^{*}$ & -.03 & $-.14 * * *$ & 1 & & & \\
\hline 12. & Income & $.11 * *$ & $.15 * * *$ & $.09 * *$ & $.14 * * *$ & $.09 * *$ & $.08^{*}$ & $.07 *$ & $.10^{*}$ & $-.30 * * *$ & .06 & $.27 * * *$ & 1 & & \\
\hline 13. & Religiosity & $.12 * * *$ & $.15 * * *$ & $.08^{*}$ & .04 & $.07 *$ & .06 & -.04 & $-.07 *$ & $.12 * * *$ & $.21 * * *$ & -.04 & $-.08 *$ & 1 & \\
\hline & $\begin{array}{l}\text { Right-wing } \\
\text { Political orientation }\end{array}$ & $-.08 *$ & $-.09 * *$ & $-.12 * * *$ & $-.11 * * *$ & .02 & .01 & $-.07 *$ & $-.07 *$ & $-.09 * *$ & $.08 *$ & .01 & $.20 * * *$ & $.18 * * *$ & 1 \\
\hline & $\begin{array}{l}\text { Global helping } \\
\text { intention toward } \\
\text { beggars }\end{array}$ & $.33 * * *$ & .36 & $.39 * * *$ & $.38 * * *$ & $.10^{* *}$ & $.07 *$ & $.17 * * *$ & $.15 * * *$ & $.14 * * *$ & $-.12 * * *$ & $.16^{* * *}$ & -.05 & $.12 * * *$ & $-.38 * * *$ \\
\hline
\end{tabular}

*** $p<.001, * * p<.01, * p<.05$ 
Table 4

Hierarchical regression analyses with heteroscedasticity consistent standard errors using the dichotomous predictor variables. The dependent variable was created by standardizing and then aggregating the 21 items measuring prosocial behavior toward beggars, then adding 1 and logarithmizing. A higher value indicates more prosocial behavior toward begging EU-migrants.

\begin{tabular}{|c|c|c|c|c|c|c|}
\hline & Block 1 & Block 2 & Block 3 & Block 4 & Block 5 & Block 6 \\
\hline & $B(\mathrm{SE} . B)$ & $B(\mathrm{SE} . B)$ & $B(\mathrm{SE} . B)$ & $B(\mathrm{SE} . B)$ & $B(\mathrm{SE} . B)$ & $B(\mathrm{SE} . B)$ \\
\hline $\begin{array}{l}\text { Donation experience in the } \\
\text { last year }\end{array}$ & $0.23(0.02)^{* * *}$ & $0.08(0.03)^{* *}$ & $0.04(0.04)$ & $0.01(0.03)$ & $-0.01(0.03)$ & $-0.01(0.03)$ \\
\hline Donation amount & & $0.03(0.01)^{* * *}$ & $0.02(0.01)^{* * *}$ & $0.03(0.01)^{* * *}$ & $0.03(0.01)^{* * *}$ & $0.02(0.01)^{* * *}$ \\
\hline $\begin{array}{l}\text { Donation to an outgroup } \\
\text { organization }\end{array}$ & & & $0.16(0.02)^{* * *}$ & $0.15(0.02)^{* * *}$ & $0.14(0.02)^{* * *}$ & $0.13(0.02)^{* * *}$ \\
\hline $\begin{array}{l}\text { Donation to an ingroup } \\
\text { organization }\end{array}$ & & & $-0.04(0.02)^{*}$ & $-0.03(0.02)$ & $-0.02(0.02)$ & $-0.00(0.02)$ \\
\hline $\begin{array}{l}\text { Donation to an } \\
\text { environmental organization }\end{array}$ & & & $0.05(0.03)^{*}$ & $0.03(0.03)$ & $0.04(0.03)$ & $0.04(0.02) \dagger$ \\
\hline Female & & & & $0.06(0.02)^{* * *}$ & $0.03(0.02) \dagger$ & $0.02(0.02)$ \\
\hline Age & & & & $-0.00(0.00)^{* * *}$ & $-0.00(0.00)^{* * *}$ & $-0.00(0.00)^{* * *}$ \\
\hline Low education & & & & & $-0.03(0.04)$ & $-0.03(0.03)$ \\
\hline High education & & & & & $0.08(0.02)^{* * *}$ & $0.07(0.02)^{* * *}$ \\
\hline Income & & & & & $-0.03(0.01)^{* * *}$ & $-0.01(0.01)$ \\
\hline Religiosity & & & & & & $0.02(0.00)^{* * *}$ \\
\hline $\begin{array}{l}\text { Rightwing political } \\
\text { inclination }\end{array}$ & & & & & & $-0.05(0.00)^{* * *}$ \\
\hline $\mathrm{R}^{2}$ & 0.104 & 0.136 & 0.183 & 0.213 & 0.243 & 0.371 \\
\hline
\end{tabular}


Table 5

Hierarchical regression analyses with heteroscedasticity consistent standard errors using the continuous predictor variables. The dependent variable was created by standardizing and the aggregating the 21 items measuring various prosocial behavior toward beggars, then adding 1 and logarithmizing. A higher value indicates more prosocial behavior toward begging EU-migrants.

\begin{tabular}{|c|c|c|c|c|c|c|}
\hline & Block 1 & Block 2 & Block 3 & Block 4 & Block 5 & Block 6 \\
\hline & $B(\mathrm{SE} . B)$ & $B(\mathrm{SE} . B)$ & $B(\mathrm{SE} . B)$ & $B(\mathrm{SE} . B)$ & $B(\mathrm{SE} . B)$ & $B(\mathrm{SE} . B)$ \\
\hline $\begin{array}{l}\text { Donation experience in the } \\
\text { last year }\end{array}$ & $0.23(0.02)^{* * *}$ & $0.08(0.03)^{* *}$ & $0.09(0.03)^{* *}$ & $0.07(0.03)^{*}$ & $0.05(0.03)$ & $0.05(0.03)$ \\
\hline Donation amount & & $0.03(0.01)^{* * *}$ & $0.02(0.01)^{* *}$ & $0.03(0.01)^{* * *}$ & $0.03(0.01)^{* * *}$ & $0.02(0.01)^{* * *}$ \\
\hline $\begin{array}{l}\text { Number of outgroup } \\
\text { organizations donated to }\end{array}$ & & & $0.06(0.01)^{* * *}$ & $0.06(0.01)^{* * *}$ & $0.05(0.01)^{* * *}$ & $0.05(0.01)^{* * *}$ \\
\hline $\begin{array}{l}\text { Number of ingroup } \\
\text { organizations donated to }\end{array}$ & & & $-0.04(0.01)^{* * *}$ & $-0.03(0.01)^{* *}$ & $-0.03(0.01)^{*}$ & $-0.02(0.01) \dagger$ \\
\hline $\begin{array}{l}\text { Number of environmental } \\
\text { organizations donated to }\end{array}$ & & & $0.02(0.02)$ & $0.01(0.02)$ & $0.02(0.02)$ & $0.02(0.02)$ \\
\hline Female & & & & $0.06(0.02)^{* * *}$ & $0.03(0.02) \dagger$ & $0.02(0.02)$ \\
\hline Age & & & & $-0.00(0.00)^{* * *}$ & $-0.00(0.00)^{* * *}$ & $-0.00(0.00)^{* * *}$ \\
\hline Low education & & & & & $-0.02(0.04)$ & $-0.02(0.04)$ \\
\hline High education & & & & & $0.08(0.02)^{* * *}$ & $0.07(0.02)^{* * *}$ \\
\hline Income & & & & & $-0.03(0.01)^{* * *}$ & $-0.01(0.01)$ \\
\hline Religiosity & & & & & & $0.02(0.00)^{* * *}$ \\
\hline $\begin{array}{l}\text { Rightwing political } \\
\text { inclination }\end{array}$ & & & & & & $-0.05(0.01)^{* * *}$ \\
\hline $\mathrm{R}^{2}$ & 0.104 & 0.136 & 0.197 & 0.222 & 0.252 & 0.378 \\
\hline
\end{tabular}


THE RELATION BETWEEN CHARITABLE DONATIONS AND HELPING BEGGARS 